\begin{tabular}{lr}
$\begin{array}{l}\text { A C T A U N I V E R S I T A T I S N I C O L A I C O P E R N I C I } \\
\text { DOI: http://dx.doi.org/10.12775/AUNC_ECON.2014.013 }\end{array}$ & EKONOMIA XLV nr 2 (2014) 205-217 \\
\hline $\begin{array}{l}\text { Pierwsza wersja złożona 18 listopada 2014 } \\
\text { Końcowa wersja zaakceptowana 20 grudnia 2014 }\end{array}$ & ISSN \\
\hline
\end{tabular}

\title{
Michat Grela*
}

\section{RYNKI PREDYKCYJNE JAKO PRZYKŁAD CROWDSOURCINGU**}

\begin{abstract}
$\mathrm{Z}$ a r y s t r e ś c i. Celem artykułu jest zaprezentowanie idei crowdsourcingu poprzez zdefiniowanie tego zjawiska i przedstawienie podstawowej typologii crowdsourcingu. W kolejnym kroku autor przedstawia w szczegółowy sposób rynki predykcyjne, które są praktycznym przykładem implementacji idei crowdsourcingu. Artykuł ma charakter opisowy i systematyzujący wiedzę o rynkach predykcyjnych.

S ło w a k l u c z o w e: crowdsourcing, rynki predykcyjne.

K 1 a s y fik a c j a J E L: G14, D79.
\end{abstract}

\section{WSTĘP}

Rozwój technologii internetowych doprowadził do zmiany roli jego użytkowników. Początkowo internauci byli wyłącznie konsumentami treści, a obecnie również kreują treści zamieszczane w przestrzeni wirtualnej (Kowalska, 2012). Zjawisko polegające na zacieraniu się granicy pomiędzy produkcją a konsumpcją nazywa się prosumpcją (Jung, 1997). Zarówno współczesne technologie internetowe, jak i powstanie prosumpcji doprowadziło do silnej ekspansji idei crowdsourcingu. Wykorzystanie mądrości tłumu umożliwiają rynki predykcyjne, które pozwalają na agregację rozproszonej wiedzy. Rynki predykcyjne w obecnej formie są znane na świecie od 1988 roku.

\footnotetext{
* Adres do korespondencji: Michał Grela, Uniwersytet Mikołaja Kopernika, Wydział Nauk Ekonomicznych i Zarządzania, ul. Gagarina 13a, 87-100 Toruń, e-mail: grela@ doktorant.umk.pl.

** Artykuł powstał na podstawie pracy magisterskiej autora pt. Rynki predykcyjne $w$ kontekście crowdsourcingu.
}

(C) 2014 Uniwersytet Mikołaja Kopernika. All rights reserved.

http://www.aunc.ekonomia.umk.pl 
Wiodącym ośrodkiem badawczym, który prowadzi badania nad rynkami predykcyjnymi, jest Centrum Zastosowań Matematyki i Inżynierii Systemów Polskiej Akademii Nauk, ale wyniki badań uzyskane przez powyższe Centrum są poufne. W literaturze polskojęzycznej jest to narzędzie w niewielkim stopniu opisane. Podstawową publikacją w języku polskim jest tłumaczenie książki o charakterze popularnonaukowym, która dotyka szeroko pojętego crowdsourcingu oraz $\mathrm{w}$ niewielkim stopniu tematyki rynków predykcyjnych (Surowiecki, 2010). W przypadku polskiej literatury naukowej z zakresu rynków predykcyjnych nie ma wielu publikacji - można wyróżnić jedną pracę, która dotyczy obszaru psychologii inwestowania na takim rynku (Mazur, 2011). Dlatego autor artykułu postanowił uzupełnić tę lukę poprzez przeglądowy artykuł o rynkach predykcyjnych.

\section{CROWDSOURCING - DEFINICJA, KLASYFIKACJA I PRZYKŁADY}

\subsection{DEFINICJA CROWDSOURCINGU}

Określenie crowdsourcing wywodzi się od połączenia dwóch angielskich słów: crowd (tłum) i source (źródło), co w wolnym tłumaczeniu oznacza „czerpanie ze źródła”. Po raz pierwszy terminu tego użył amerykański dziennikarz Howe (2006), ale samo zjawisko jest znane od początków XX wieku. Howe (2006) zdefiniował crowdsourcing jako ,przekazanie przez firmę lub instytucję funkcji, które były wykonywane przez pracowników lub firmy zewnętrzne, nieokreślonej (zazwyczaj dużej) grupie osób. Przy czym funkcja ta może być realizowana przez osoby indywidualne". Warto dodać, że kluczowym elementem crowdsu jest otwarte zaproszenie do uczestnictwa, co daje dużą sieć potencjalnych zaangażowanych.

Genezy crowdsourcingu można doszukiwać się w eksperymencie przeprowadzonym w 1906 roku przez brytyjskiego uczonego Francisa Galtona. Eksperyment pokazał, że tłum może podejmować poprawne decyzje. Galton poprosił uczestników West of England Fat Stock and Poultry Exhibition o oszacowanie wagi wołu po zabiciu i oprawieniu. Uczony zebrał szacowania od blisko 800 osób i policzył medianę. Okazało się, że średnia szacunków uczestników wystawy wynosiła 1197 funtów, przy czym waga wołu wynosiła 1198 (Galton, 1906).

\subsection{RODZAJE I TYPOLOGIA CROWDSOURCINGU}

W praktyce do crowdsourcingu zalicza się bardzo wiele różnych form działalności, należą do nich m.in.: 
a) rozwiązywanie problemów przez tłum - inteligencja zbiorowa (collective intelligence, wisdom of the crowd),

b) wykorzystanie potencjału twórczego użytkowników - tworzenie wartości przez tłum (crowdcreation, user-generated content),

c) zlecanie tłumowi wyboru najlepszych rozwiązań (crowdvoting),

d) społecznościowe pozyskiwanie funduszy (crowdfounding),

e) mikropraca (microwork),

f) nakłanianie do udziału w konkursach (inducement prize contests),

g) nabywanie dóbr grupowo w celu uzyskania lepszej oferty (crowdpurchasing),

h) utajony crowdsourcing (implicit crowdsourcing).

Tabela 1. Typologia crowdsourcingu

\begin{tabular}{|c|c|c|c|}
\hline Typ & Zasada działania & Rodzaje problemów & Przykłady \\
\hline $\begin{array}{l}\text { Zarządzanie i wyszuki- } \\
\text { wanie wiedzy }\end{array}$ & $\begin{array}{c}\text { Wyszukiwanie } \\
\text { i gromadzenie informacji }\end{array}$ & $\begin{array}{l}\text { Do gromadzenia, } \\
\text { organizacji } \\
\text { i raportowania } \\
\text { problemów, np. } \\
\text { Zasobów zbiorowych }\end{array}$ & $\begin{array}{l}\text { Peer-to-Patent } \\
\text { peertopatent.org } \\
\text { SeeClickFix } \\
\text { seeclickfix.com }\end{array}$ \\
\hline $\begin{array}{l}\text { Przekazywanie } \\
\text { poszukiwań }\end{array}$ & $\begin{array}{c}\text { Rozwiazywanie } \\
\text { empirycznych problemów }\end{array}$ & $\begin{array}{l}\text { Do rozwiazywania } \\
\text { empirycznych } \\
\text { problemów, takich } \\
\text { jak problemy } \\
\text { naukowe }\end{array}$ & $\begin{array}{c}\text { InnoCentive } \\
\text { innocentive.com } \\
\text { Goldcorp Challenge } \\
\text { Defunct.com }\end{array}$ \\
\hline & & & $\begin{array}{c}\text { Threadless } \\
\text { threadless.com }\end{array}$ \\
\hline $\begin{array}{l}\text { Przekazywanie zadań } \\
\text { kreatywnych }\end{array}$ & $\begin{array}{c}\text { Generowanie i ocenianie } \\
\text { pomysłów }\end{array}$ & $\begin{array}{l}\text { Do wsparcia firm } \\
\text { w procesie } \\
\text { generowania oferty } \\
\text { produktowej }\end{array}$ & $\begin{array}{l}\text { Doritos Crash the Su- } \\
\text { per Bowl Contest } \\
\text { crashthesuperbowl.com } \\
\text { Next Stop Design } \\
\text { nextstopdesign.com }\end{array}$ \\
\hline $\begin{array}{l}\text { Wykorzystywanie } \\
\text { ludzkiej inteligencji }\end{array}$ & $\begin{array}{c}\text { Analiza dużych zbiorów } \\
\text { informacji }\end{array}$ & $\begin{array}{l}\text { Do analizy dużych } \\
\text { zbiorów danych, } \\
\text { w których ludzka } \\
\text { inteligencja jest } \\
\text { efektywniesza } \\
\text { i skuteczniejsza niż } \\
\text { analizy } \\
\text { komputerowe }\end{array}$ & $\begin{array}{c}\text { Amazon Mechanical } \\
\text { Turk } \\
\text { mturk.com } \\
\text { Subvert and Profit } \\
\text { subvertandprofit.com }\end{array}$ \\
\hline
\end{tabular}

Źródło: Brabham (2012).

Bardzo ważnym aspektem crowdsourcingu jest motywacja do uczestnictwa w danym przedsięwzięciu, ponieważ każdego z uczestników motywują 
inne elementy. Do podstawowych czynników motywujących można zaliczyć:

a) możliwość zarabiania pieniędzy,

b) rozwijanie własnych umiejętności,

c) budowanie sieci kontaktów z profesjonalistami z danej branży,

d) budowanie 208ort folio do przyszłej pracy,

e) rozwiązywanie trudnych problemów,

f) budowanie relacji towarzyskich,

g) rozwijanie własnych zainteresowań,

h) możliwość rozrywki.

W literaturze przedmiotu wyróżniane są cztery podstawowe typy crowdsourcingu. Podział ten jest zdeterminowany funkcją, jaka jest przekazywana społeczności. Podstawowe porównanie typów crowdsourcingu znajduje się w tabeli 1 .

Obecnie crowdsourcing przeżywa fazę rozkwitu, dlatego powyższa typologia staje się niewystarczająca. W związku z tym następuje konieczność rozbudowania tej typologii - niestety, w literaturze nie występują bardziej rozbudowane typologie, które pozwalają na łatwe dostosowanie ich do panujących warunków.

\subsection{ZALETY I WADY CROWDSOURCINGU}

Istotnym elementem obszaru badań nad crowdsourcingiem są jego wady i zalety. Zanim firma bądź instytucja zdecyduje się na zastosowanie tej formy wsparcia biznesu, musi przeanalizować korzyści i koszty wynikające $\mathrm{z}$ tego rozwiązania. Do podstawowych zalet crowdsourcingu można zaliczyć:

1. Możliwość uzyskania pozytywnego wyniku taniej niż za pomocą innych rozwiązań.

2. Możliwość uzyskania innego spojrzenia na problem i wykorzystania kreatywności dużej grupy ludzi.

3. Brak konieczności ciągłego nadzorowania grupy realizującej zadanie.

4. Bardzo dobre narzędzie marketingu.

5. Możliwość znalezienia utalentowanych pracowników.

6. Możliwość zredukowania kosztownego działu R\&D.

Crowdsourcing nie jest również pozbawiony wad, do których można zaliczyć:

1. Możliwość łatwiejszego pozyskania informacji o firmie przez konkurencję.

2. Możliwość plagiatów przez niektórych członków tłumu. 
3. Możliwość zniechęcenia pracowników do efektywnego działania.

4. Możliwość uzyskania niepożądanych efektów.

\section{RYNKI PREDYKCYJNE}

Pierwszy rynek predykcyjny we współczesnej formie powstał w 1988 roku na Uniwersytecie w Iowa i nosił nazwę Iowa Political Stock Market (Rhode, Strumpf, 2008) (obecnie Iowa Electronic Markets - IEM). Jego twórcami są Robert Forsythe, Forrest Nelson i George Neumann (Danielson, 2010). Przedmiotem tego rynku były wybory stanowe i prezydenckie w Stanach Zjednoczonych (Luckner, 2010). Jednakże można wyróżnić historyczne rynki predykcyjne, które funkcjonowały na przestrzeni XVI i XX wieku (Rhode, Strumpf, 2008). Różnią się one znacznie pod kilkoma względami od współczesnych rynków predykcyjnych, gdzie najważniejszy jest cel działania. W przypadku historycznych rynków predykcyjnych podstawowym celem było generowanie zysków i pod tym względem nie różnią się one od współczesnych zakładów bukmacherskich. Natomiast stosowane współcześnie rynki predykcyjne mają na celu otrzymanie trafnych prognoz, które są reprezentowane przez cenę rynkową. Nie zmienia to faktu, że historyczne rynki predykcyjne mogły stanowić inspirację do współczesnych aplikacji.

\subsection{DEFINICJA RYNKÓW PREDYKCYJNYCH}

Mimo że rynki predykcyjne są coraz bardziej popularne, nie wykształciła się jednolita terminologia i jedna powszechnie akceptowalna definicja. W literaturze anglojęzycznej terminów, które określają to zagadnienie, jest wiele, zaliczamy do nich: prediction markets, information markets, virtual markets, decision markets, idea futures, forecasting markets, artificial markets, electronic markets, virtual stock markets (Luckner, 2008), event futures, electronic futures markets (Olivien, Rietz, 2004), idea markets (Slamka, Jank, Skiera, 2012). Powyższe określenia mają odzwierciedlenie w rzeczywistości i są powiązane $\mathrm{z}$ wieloma aspektami działania rynków predykcyjnych, tj. cel i mechanizm działania. W polskiej terminologii zostało przyjęte określenie rynki predykcyjne. Dobrym zobrazowaniem zróżnicowania w stosowanej terminologii może być liczba artykułów używających danego terminu.

Mimo zróżnicowanej terminologii istnieje jednolita definicja rynków predykcyjnych. Rynek predykcyjny to „,specyficzny rynek finansowy, na którym przedmiotem obrotu są kontrakty terminowe na procent szans na zajście określonego wydarzenia. Innymi słowy: gracze zawierający ze sobą kontrakt zakładają się ze sobą, czy dane zdarzenie nastąpi, czy też nie" 
(http://www.maths.com.pl/?w=1\&q=rynki). Alternatywną definicją rynków predykcyjnych może być: rynek predykcyjny to specyficzny rynek finansowy, na którym przedmiotem obrotu są kontrakty/zakłady na zaistnienie zdarzeń w przyszłości. W najprostszej formie takiego rynku gracze zakładają się, czy pewne zdarzenie w przyszłości będzie miało miejsce, czy też nie. Kurs, który ustala się na rynku, można traktować jako subiektywną miarę prawdopodobieństwa (Bayes, Price, 1763) zaistnienia zdarzenia w przyszłości, bazującą na zagregowanej wiedzy osób uczestniczących w rynku (Hayek, 1945).

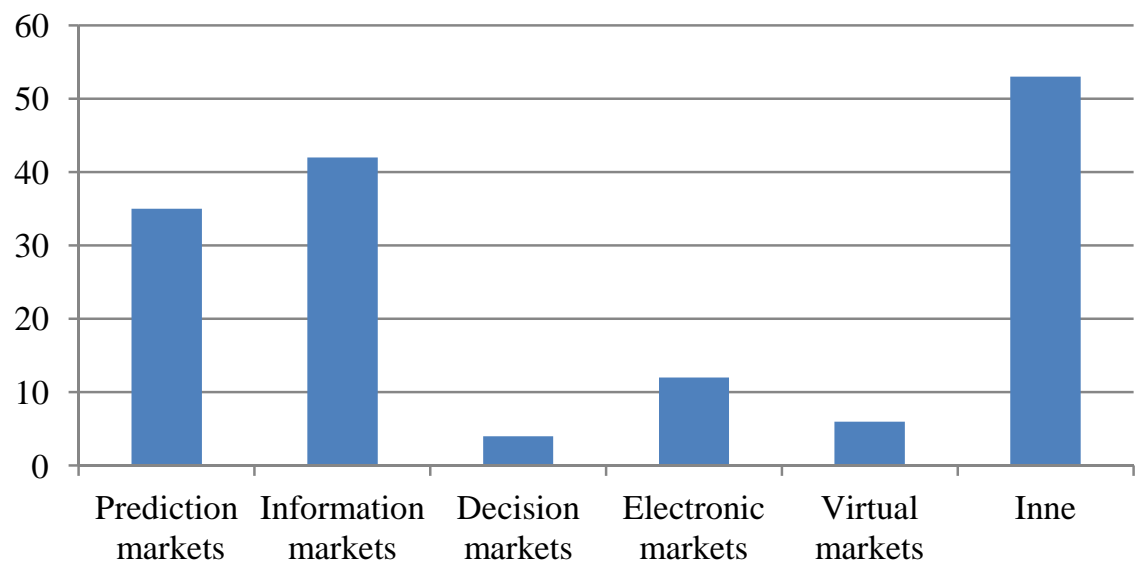

Rysunek 1. Liczba artykułów, w których używany jest dany termin Źródło: Tziralis, Tatsiopoulos (2007).

\subsection{PODSTAWY DZIAEANIA RYNKÓW PREDYKCYJNYCH}

Rynki predykcyjne sprawdziły się w wielu zastosowaniach. W związku z tym kolejnym krokiem jest określenie mechanizmu, który sprawia, że rynki predykcyjne sprawdzają się w praktyce. W tym aspekcie należy wyróżnić trzy główne elementy, które wpływają na skuteczność rynków predykcyjnych, są to: idea crowdsourcingu, motywacja ekonomiczna lub pozaekonomiczna (np. prestiż) oraz hipoteza efektywnego rynku.

Idea „,mądrości tłumu” została opisana w pierwszej części artykułu, co pozwala zauważyć pewne powiązania między crowdsourcingiem a rynkami predykcyjnymi. Rynki predykcyjne są doskonałą implementacją idei crowdsourcingu w praktyce. Przejawia się to tym, że tłum, często nie mający specjalistycznej wiedzy, ale posiadający wiedzę rozproszoną, potrafi zagregować tę informację. 
Kluczową kwestią w wyjaśnieniu fenomenu tego zjawiska jest motywacja ekonomiczna lub pozaekonomiczna. Konieczność przeznaczenia pewnej kwoty na zawarcie kontraktu zmienia punkt widzenia. Gracze bowiem nie odpowiadają na pytanie, jakie są ich preferencje odnośnie do zdarzenia, ale jak oceniają szanse jego zajścia. W związku z powyższym stawka kontraktu na rynku przekształca się $\mathrm{w}$ subiektywne oszacowanie miary prawdopodobieństwa.

Warto zauważyć, że rynki predykcyjne, jako szczególny przykład rynków finansowych, także podlegają hipotezie efektywnego rynku. Wynika $\mathrm{z}$ tego, że jeżeli rynek predykcyjny jest płynny, a gracze rozumieją wpływ na zajście zdarzenia, kurs kontraktów w sposób maksymalnie dokładny oddaje dostępne powszechnie informacje.

Ostatnią kwestią jest znalezienie odpowiedzi na pytanie, dlaczego kurs kontraktów na rynku predykcyjnym, będący wypadkową subiektywnych oszacowań prawdopodobieństwa niereprezentatywnej grupy ludzi, ma być dobrym oszacowaniem szans na zajście zdarzenia. Zwolennicy rynków predykcyjnych opierają się na tłumaczeniu tego zjawiska teorią stworzoną w 1945 roku przez austriackiego ekonomistę F.A. Hayeka. Hayek stwierdził, że ceny agregują „rozproszone cząstki niekompletnej i często sprzecznej wiedzy, którą wszystkie jednostki posiadają" (Hayek, 1945). Podstawy funkcjonowania rynków predykcyjnych były wielokrotnie modelowane za pomocą teoretycznych modeli matematycznych, m.in. przez takich autorów, jak Zitzewitz, Wolfers (2004, 2005), Manski (2004), Hanson (2003). Dodatkowo analizując rynki predykcyjne, warto uwzględnić aspekty psychologiczne, które mają istotny wpływ na podejmowanie decyzji (Mazur, 2011).

\subsection{PRAKTYCZNE ASPEKTY PROJEKTOWANIA RYNKÓW PREDYKCYJNYCH}

Projektowanie rynków predykcyjnych jest procesem, który wymaga przygotowania wielu aspektów. Podczas tego procesu warto rozróżnić dwie główne grupy działań przygotowawczych. Pierwsza grupa związana jest ogólnie z samym rynkiem, a druga z jego uczestnikami.

Projektując rynek predykcyjny, należy w pierwszej kolejności określić jego cel oraz tematykę. Celem rynku predykcyjnego może być prognozowanie różnorakich zdarzeń, agregacja informacji oraz zbieranie opinii uczestników rynku. W przypadku tematyki rynku istnieje pełna dowolność (istnieją rynki o tematyce ogólnej, biznesowej, politycznej, filmowej). 


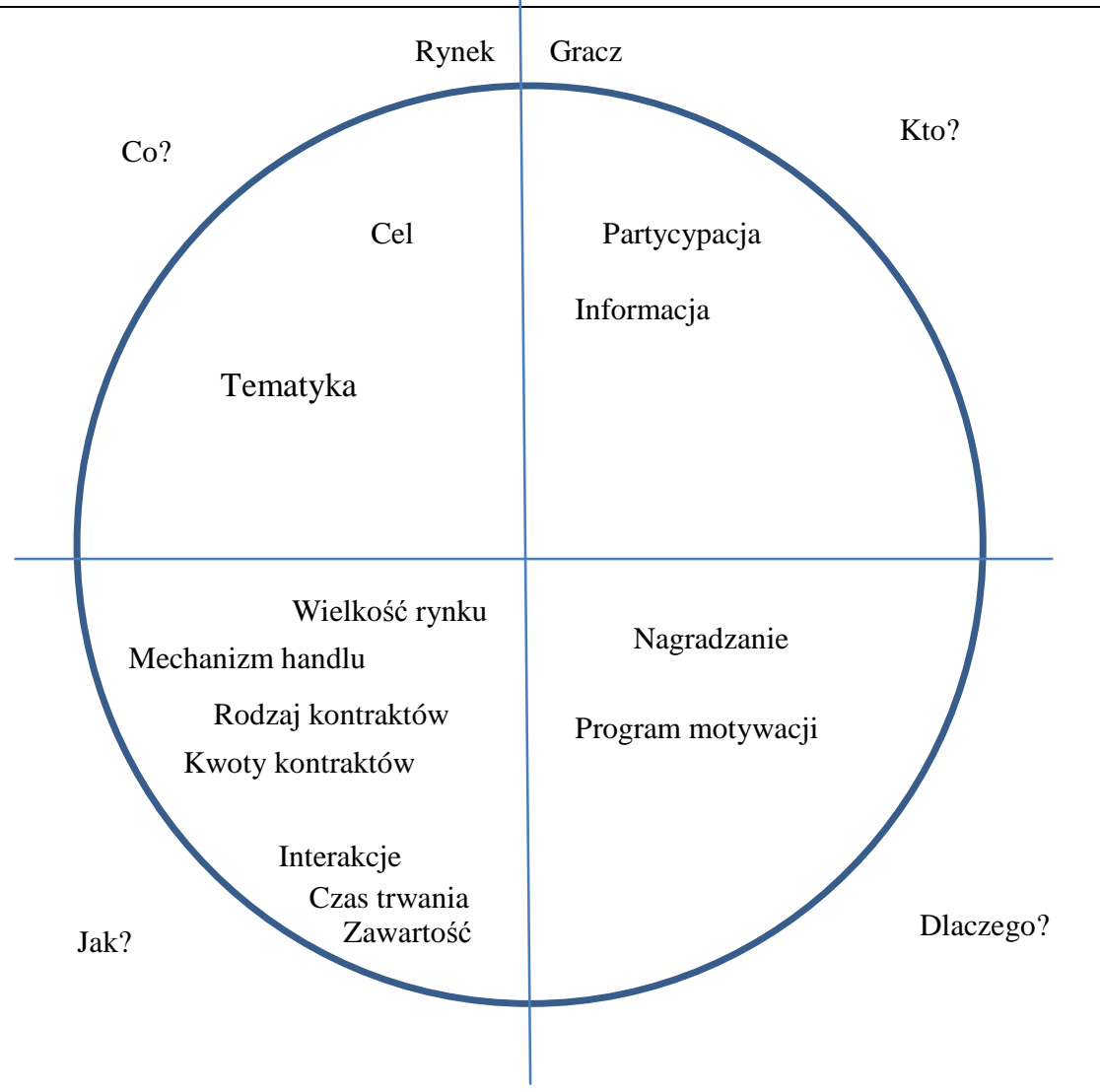

Schemat 1. Aspekty projektowania rynków predykcyjnych

Źródło: Geifman, Raban, Rafaeli (2011).

Kolejnymi parametrami rynku, które powinny zostać ustalone przed jego uruchomieniem, jest jego wielkość (ilu musi być uczestników, żeby rynek dobrze funkcjonował), czas trwania, kwoty kontraktów oraz sama zawartość merytoryczna. Bardzo ważnym aspektem jest określenie rodzaju waluty. Mianowicie może to być waluta realna bądź wirtualna - bardzo często wybór waluty jest implikowany przez prawo w danych państwie. Kolejnym elementem projektowania rynku jest określenie, czy na rynku powinna zachodzić interakcja między graczami. Jednymi z najważniejszych elementów jest określenie rodzaju kontraktów oraz mechanizmu handlu.

Każdy z typów kontraktów daje inne wypłaty dla graczy, które powiązane są z nieznanymi przyszłymi zdarzeniami. W związku z tym wybór odpowiedniego rodzaju kontraktów implikuje otrzymaną informację zwrotną z rynku. Wyróżniamy trzy podstawowe rodzaje kontraktów: winner-takes- 
all, index, spread (Wolfers, Zitzewitz, 2004). Poza nimi można wyróżnić bardziej skomplikowane kontrakty lub kombinacje podstawowych trzech: volume weighted (Geifman, Raban, Rafaeli, 2011). Podstawowe charakterystyki poszczególnych rodzajów kontraktów zostały zaprezentowane w poniżej tabeli.

Tabela 2. Rodzaje kontraktów

\begin{tabular}{|c|c|c|c|}
\hline Rodzaje kontraktów & Przykład & Wypłata & Prognoza \\
\hline Winner-takes-all & $\begin{array}{c}\text { Sprzedaż produktu X } \\
\text { będzie wyższa niż } \\
\text { w zeszłym roku }\end{array}$ & $\begin{array}{c}1 \$ \text { jeśli zdarzenie } \\
\text { zajdzie } 0 \$ \\
\text { w przeciwnym wypadku }\end{array}$ & $\begin{array}{c}\text { Prawdopodobieństwo } \\
\text { zajścia zdarzenia }\end{array}$ \\
\hline Index & $\begin{array}{c}\text { Procentowy udział w rynku } \\
\text { produktu X w przyszłym }\end{array}$ & $\begin{array}{l}0,01 \$ \text { za każdy punkt } \\
\text { procentowy }\end{array}$ & $\begin{array}{c}\text { Wartość oczekiwana } \\
\text { dochodu }\end{array}$ \\
\hline Spread & $\begin{array}{c}\text { Sprzedaż produktu X } \\
\text { w przyszłym zwiększy się } \\
\text { więcej niż y\% }\end{array}$ & $\begin{array}{l}2 \$ \text { jeżeli spread } \\
\text { zostanie } \\
\text { przekroczony } \\
\text { a w przeciwnym } \\
\text { wypadku 0\$ }\end{array}$ & Wartość mediany \\
\hline
\end{tabular}

Źródło: Luckner (2012).

Obok wyboru rodzaju kontraktów ważnym aspektem projektowania rynku predykcyjnego jest określenie mechanizmu handlu. Można wyróżnić kilka podstawowych mechanizmów handlu: ciągła aukcja podwójna (continuous double auction, CDA), system jednolitej ceny (call auction, CA), dynamic pari-mutuel market (DPM) i market scoring rules (MSR) (Geifman, Raban, Rafaeli, 2011). Podstawowymi kryteriami opisu mechanizmów handlu na rynkach predykcyjnych są: możliwość ciągłej agregacji informacji (np. uwzględnienie informacji, które pojawiły się po zawarciu kontraktów), gwarancja płynności rynku oraz ryzyko finansowe dla twórców rynku (Luckner, 2008).

W przypadku gracza należy ustalić dwa podstawowe elementy. Mianowicie, kto powinien grać na zaprojektowanym rynku oraz dlaczego chciałby grać. W pierwszym aspekcie należy dokonać wyboru, w jaki sposób powinni być dopierani gracze (zapraszani przez organizatora rynku, czy poprzez rejestrację na platformie rynku predykcyjnego). Sposób zapraszania uczestników rynku jest silnie związany z tym, jaką informację powinni oni posiadać, ponieważ do przykładowo bardzo specjalistycznego rynku nie chcemy zapraszać kogokolwiek, ale specjalistów dziedzinowych. W zakresie motywacji do gry należy określić sposób nagradzania graczy oraz program motywacyjny. 


\subsection{PRZYKŁADY RYNKÓW PREDYKCYJNYCH}

Wykorzystanie rynków predykcyjnych jako narzędzia wspomagania decyzji $\mathrm{w}$ przedsiębiorstwie stało się $\mathrm{w}$ ostatnich latach powszechne. Jedną z globalnych firm, która używa rynków predykcyjnych, jest HP. Rynki predykcyjne uruchamiane przez HP można podzielić na dwa rodzaje (z perspektywy celu): rynek służący do prognozowania miesięcznej sprzedaży drukarek na trzy miesiące do przodu oraz rynek służący do prognozowania kosztów związanych z zakupem pamięci DRAM.

Pierwszy rynek predykcyjny w HP został uruchomiony w 1996 roku. Rynek ten miał charakter eksperymentalny i funkcjonował przez tydzien, przy czym uczestnicy grali głównie wieczorami i podczas przerw w pracy. Uczestnikami rynku były osoby zaangażowane w podejmowanie decyzji (od 7 do 26 osób), które pracowały w działach finansowych i marketingowych firmy. Wszyscy uczestnicy byli anonimowi, przeszli podstawowe szkolenie oraz zostali poinformowani o celach eksperymentu. Gracze otrzymywali kwotę startową na poziomie 50\$, a następnie mogli zakładać się o to, jaki przedział sprzedaży drukarek zostanie osiągnięty. Mechanizm zakładania się był oparty na aukcji podwójnej i w sposobie działania przypominał kontrakty futures. Efektem eksperymentu były prognozy dokładniejsze od oficjalnych prognoz zarządu w 75\% przypadków (Ho, Chen, 2007).

Eli Lilly jest jedną z największych firm farmaceutycznych na świecie. Każdego roku firma traci wiele milionów dolarów na skutek prowadzenia badań nad lekami, które okazują się nietrafione (odrzucone przez rynek lub komisje farmaceutyczne). W związku z tym każda dodatkowa informacja, w jakie badania inwestować, może pozwolić na ogromne oszczędności. Jedną z metod, jakie w tym celu zastosowano w Eli Lilly, były rynki predykcyjne. Pierwszy rynek na potrzeby Eli Lilly został stworzony przez firmę NewsFutures. Tematyka rynku dotyczyła powodzenia projektów farmaceutycznych, a tym samym wprowadzenia leków na rynek. Mechanizmem funkcjonującym na rynku była wirtualna gra giełdowa, która przypominała handel akcjami. Uczestnikami rynku byli pracownicy firmy, którzy aktywnie uczestniczyli w procesie badań farmaceutycznych. Rynek liczył około pięćdziesięciu osób, głównie chemików, biologów, farmaceutów i osób zajmujących się zarządzaniem projektami. Na uruchomionym rynku gracze, handlując akcjami sześciu leków, prognozowali rzeczywistą wartość rynkową poszczególnych leków. Okazało się, że rynek trafnie wskazał 3 leki, które osiągnęły największy sukces (Kiviat, 2004).

Futarchia jest jedną z form ustroju politycznego, którego pomysłodawcą jest Robin Hanson. Hanson uważa, że demokracja ma pewne istotne wady, 
które mogą zostać wyeliminowane przez zastosowanie rynków jako narzędzia wspomagającego podejmowanie decyzji. Należy przede wszystkim zdefiniować wskaźniki, które określają stan państwa w danym momencie. Następnie gracze na rynkach określaliby, jak proponowane decyzję wpłyną według nich na ustalony wskaźnik. Mechanizm przewidywania byłby zbliżony do tradycyjnych rynków, gdzie uczestnicy oferują pewną kwotę za dany produkt i zostaje ustalona cena. W przypadku utarchii cena oznaczałaby oczekiwaną wartość wskaźnika (Hanson, 2013).

Microsoft zaczął używać rynków predykcyjnych w 2003 roku. Pierwszy uruchomiony rynek nazywał się „Information Forecasting Exchange” (IFE). Działał on w niepełnym wymiarze godzin i uruchamiany był głównie wieczorami i w weekendy. Tematyką rynku było zarządzanie projektami (dotrzymanie terminu realizacji projektu). Od 2006 roku Microsoft rozszerzył działania w ramach rynków predykcyjnych (PredictionPoint) na (obok zarządzania projektami) prognozowanie liczby błędów w oprogramowaniu. Mechanizmem działania tych rynków były Market Scoring Rules (MSR), które zaproponował R. Hanson (Jian, Sami, 2013).

\section{PODSUMOWANIE}

Mimo rosnącej popularności rynków predykcyjnych ich rozwój napotyka przeróżne bariery. Podstawowymi ograniczeniami rozwoju rynków predykcyjnych są bariery prawne oraz bariery mentalne. W przypadku tych pierwszych problemem jest traktowanie rynków predykcyjnych jako działalności hazardowej lub inwestycyjnej, co pociąga za sobą posiadanie koncesji. Protest przeciwko takim rozwiązaniom podpisało wielu wybitnych ekonomistów. W niektórych państwach problem ten został rozwiązany. Przykładowo w Stanach Zjednoczonych można prowadzić rynek predykcyjny w celach badawczych, np. IEM. Druga bariera dotyczy postrzegania rynków predykcyjnych przez przedsiębiorców. Związane to jest z brakiem wiedzy na temat zjawiska crowdsourcingu.

Mimo tych ograniczeń powstaje wiele rynków predykcyjnych na świecie. W najbliższym czasie zostanie ponownie uruchomiony rynek predykcyjny Intrade, który został zamknięty z powodów prawnych. Ponowne uruchomienie tego rynku może mieć silny wpływ na postrzeganie i perspektywy rynków predykcyjnych w najbliższej przyszłości. Innym przykładem, który pokazuje, że rynki predykcyjne się rozwijają jest Good Judgement Project. Good Judgement Project jest to rynek predykcyjny uruchomiony przez amerykańską agencję IARPA, którego celem jest przewidywanie zdarzeń społecznych i geopolitycznych. Warto zaznaczyć, że również w Polsce funkcjonuje rynek predykcyjny - Logiczny Ekstraktor Możliwości NANO (L.E.M. 
NANO). Rynek ten został uruchomiony w kwietniu 2014 roku przez Agencję Rozwoju Przemysłu SA oraz Centrum Zastosowań Matematyki i Inżynierii Systemów Polskiej Akademii Nauk, a jego celem jest przewidywanie zastosowań komercyjnych i badawczych nowoczesnych technologii ze szczególnym uwzględnieniem grafenu.

\section{LITERATURA}

Bayes M., Price M. (1763), An Essay towards Solving a Problem in the Doctrine of Chances. By the Late Rev. Mr. Bayes, F. R. S. Communicated by Mr. Price, in a Letter to John Canton, Philosophical Transaction, 53, 370-418.

Brabham D. (2012), Crowdsourcing: A Model for Leveraging Online Communities, [w:] Delwiche A., Henderson J. (red.), The Participatory Cultures Handbook, New York.

Danielson M. (2010), Prediction Markets, http://www.slideserve.com/dewey/predictionmarkets (09.03.2015).

Galton F. (1907), Vox Populi, "Nature", 450, DOI: http://dx.doi.org/10.1038/075450a0.

Geifman D., Raban D., Rafaeli S. (2011), P-MART: Towards a classification of online prediction market, http://firstmonday.org/ojs/index.php/fm/article/view/3203/3019 (03.06.2014).

Hanson R. (2003), Combinatorial Information Market Design, „Information Systems Frontiers", 5, 107-119.

Hayek F. A. (1945), The use of knowledge in society, „The American Economic Review”, 35, 519-530.

Ho T., Chen K. (2007), New Product Blockbusters: The Magic and Science of Prediction Markets, http://faculty.haas.berkeley.edu/hoteck/papers/cmr.pdf (09.03.2015).

Howe J. (2006), The Rise of Crowdsourcing, http://www.disco.ethz.ch/lectures/fs10/seminar/paper/michael-8.pdf (09.03.2015).

Jung B. (1997), Kapitalizm postmodernistyczny, „Ekonomista”, 5-6, 715-735.

Kiviat B. (2004), The end of management?, http://content.time.com/time/magazine/article/0,9171,660965,00.html (07.09.2014).

Kowalska M. (2012), Wykorzystywanie mądrości ttumu w działalności bibliotek, „Toruńskie Studia Bibliologiczne", 2(9), 99-112.

Manski C. F. (2004), Interpreting the Predictions of Prediction Markets, http://www.aeaweb.org/assa/2006/0106_1015_0703.pdf (05.09.2012).

Mazur K. (2011), Podejmowanie decyzji w warunkach ryzyka - badanie zachowań graczy na rynkach predykcyjnych, http://www.academia.edu/1565589/Podejmowanie_decyzji_w_warunkach_ryzykabadanie_zachowa\%C5\%84_graczy_na_rynkach_predykcyjnych (07.09.2013).

Rhode P. W., Strumpf K. (2008), Historical Political Futures Markets: An International Perspective, Working Paper 14377, NBER Working Paper Series, Cambridge.

Slamka Ch., Jank W., Skiera B. (2012), Second-Generation Prediction Markets for Information Aggregation: A Comparison of Payoff Mechanism, „Journal of Forecasting”, 31, 469-489.

Surowiecki J. (2010), Mądrość ttumu. Większość ma rację w ekonomii, biznesie i polityce, Wydawnictwo HELION, Gliwice.

Tziralis G., Tatsiopoulos I. (2007), Prediction Markets: An Extended Literature Review, „Journal of Prediction Markets”, 1, 75-91. 
Wolfers J., Zitzewitz E. (2004), Prediction markets, „Journal of Economic Perspectives”, 18, $107-126$.

Wolfers J., Zitzewitz E. (2005), Five Open Questions About Prediction Markets, http://www.dartmouth.edu/ ericz/FiveQuestions.pdf (05.09.2012).

\section{PREDICTION MARKETS AS AN EXAMPLE OF CROWDSOURCING}

A b s tract. The aim of of this article is present the idea of crowdsourcing by defining this phenomenon and to provide basic typology of crowdsourcing. In the next step, the author presents in detail the prediction markets, which are a practical example of the implementation of the idea of crowdsourcing. The article is descriptive and systematizing knowledge of the prediction markets.

K e y w o r d s: crowdsourcing, prediction markets. 
